\title{
The study of a total and two hypothalamic- specific BBS10 knockout models highlights the importance of systemic inactivation in the obese phenotype in Bardet Biedl Syndrome
}

\author{
M Scerbo $^{1 *}$, F Costa $^{1}$, C Obringer $^{2}$, H Dollfus ${ }^{1,2}$, V Marion $^{1}$ \\ From Cilia 2014 - Second International Conference \\ Paris, France. 18-21 November 2014
}

The autosomal recessive disorder, Bardet-Biedl syndrome (BBS) is an iconic ciliopathy, clinically characterized by obesity, retinopathy, polydactyly and renal dysfunction. To date, 19 BBS genes have been identified, with BBS10 being one of the most commonly mutated genes in human patients. The historical origin of the BBS-induced obesity has been associated with leptin resistance correlated with hyperleptinemia as well as decreased signaling in the appetite-governing arcuate nucleus neurons (ARC) of the hypothalamus. The ARC controls energy homeostasis, food intake and energy expenditure, through the detection of peripheral hormones by POMC and AgRP/ NPY expressing neurons. POMC neurons are anorexigenic while NPY/AgRP are orexigenic, and both are ciliated cells. Several hormone receptors have ciliary localization, as the leptin receptor, and inactivation of the BBS proteins results in their mislocalization and signaling impairment. The present work aims at investigating the origins of obesity in the BBS by comparing the phenotype of a $B B S 10$ total knockout $\left(B b s 10^{-/-}\right)$with that of two $B B S 10$ hypothalamic-specific KO mice: namely the POMC $\left(B b s 10^{f l / f l} ; P O M C-C r e^{+/}\right)$and the AgRP $\left(B b s 10^{f l f f l}\right.$; $\left.\mathrm{AgRP}-\mathrm{Cr} \mathrm{C}^{+/}\right) . \mathrm{Bbs} \mathrm{O}^{-/-}$mice develop obesity, together with other BBS cardinal traits, but surprisingly, both $B b s 10^{f l f l}$; $\mathrm{AgRP}-\mathrm{Cr} \mathrm{e}^{+/-}$and $\mathrm{Bbs} 10^{f l / f l} ; \mathrm{POMC}-\mathrm{Cr} e^{+/-}$display a lean phenotype. Further characterizations of these mice highlighted the activation of compensatory mechanisms in response to the specific BBS10 inactivation probably forestalling the obese phenotype. These results indicate the complexity of the BBS-related obese phenotype, and

'Laboratoire de Génétique Médicale, INSERM, UMR-U1112, Université de Strasbourg, Strasbourg, France

Full list of author information is available at the end of the article support the need for an integrative approach that would include the contribution of other peripheral organs to better understand the origins of obesity in BBS.

\section{Authors' details}

'Laboratoire de Génétique Médicale, INSERM, UMR-U1112, Université de Strasbourg, Strasbourg, France. ${ }^{2}$ Hôpitaux Universitaires de Strasbourg, Strasbourg, France.

Published: 13 July 2015

\section{doi:10.1186/2046-2530-4-S1-P5}

Cite this article as: Scerbo et al: The study of a total and two hypothalamic-specific BBS10 knockout models highlights the importance of systemic inactivation in the obese phenotype in Bardet Biedl Syndrome. Cilia 2015 4(Suppl 1):P5.

Submit your next manuscript to BioMed Central and take full advantage of:

- Convenient online submission

- Thorough peer review

- No space constraints or color figure charges

- Immediate publication on acceptance

- Inclusion in PubMed, CAS, Scopus and Google Scholar

- Research which is freely available for redistribution 